\title{
Linguistics Categories and Expression Of Nonverbal In Buka Bumi "Nyadran" Ceremony Of Javanese Mountain Farmers In Wonokromo Village, Alian, Kebumen (Anthropolinguistics Studies)
}

\author{
Rudiyanto $^{1}$, Wakit Abdullah ${ }^{2}$, Dwi Purnanto ${ }^{3}$ \\ \{yrudi0324@gmail.com\} \\ Student of Master Programin Linguistics Studies, Sebelas Maret University of Surakarta ${ }^{1}$, Professor \\ of Humanities Faculty, Sebelas Maret University of Surakarta², Lecturer of Master Program in Linguistic \\ Studies, Sebelas Maret University of Surakarta ${ }^{3}$
}

\begin{abstract}
This study aims to describe the linguistics categories and expression of nonverbal in language and culture of Javanese Mountain Farmers in Wonokromo, Alian, Kebumen. This study is a qualitative descriptive method. The approach used in the study is an anthropolinguistics with ethnography methods and the ethnos ins model as an analysis model. The result of the study is describe a linguistics categories that are found in the agricultural domain especially mountains farming society. These include in processing, harvesting and equipment used in agriculture. The study also described the nonverbal expression that contained of cultural meaning in traditions still preserved by the farming society in the Wonokromo Village. These nonverbal expressions are as a means of making a harmonious life and as a form of gratitude to the God almighty. This expressions of nonverbal is reflected in rituals that include of nyadran tradition. This ceremony has the purpose for honoring the ancestors and dhayang that are especially of Dewi Sri. The consecration is embodied in the offering 'sajen' as an agent to draw close to God almighty.
\end{abstract}

Keywords: linguistics categories, nonverbal expression, mountain farming, anthropolinguistics

\section{Introduction}

Culture is a reflection of people's life that shows the characteristics of a nation. Culture is the result of the creation and taste of humans such as beliefs, knowledge, customs, and others [1]. This culture is also inseparable from the language used by a cultural community. This is because language is an element of culture itself. With language, culture will always live in the midst of technological development. This means that language and culture are a unit that has an inseparable relationship. The most basic relationship between language and culture is that language is studied in a cultural context, while culture can be learned through language.

Language as a communication tool is not only used to communicate in life in society. However, language is also a part of culture which has a function as a tool to reveal the meaning contained in the culture of a society. Language is also a concrete form of the use of language itself. Language is not only studied for its structure, but for speakers, the use of language and 
the meaning contained in the cultural context need to be studied in depth. Speakers who are meant to refer to individuals in a social community in accordance with the context of their society. The intended context is in the form of traditions that exist in the hill farmer community.

Research related to traditions in agriculture is one way to record and explore traditional knowledge which is reflected in verbal and nonverbal expressions. This tradition is maintained by the farming community to overcome various problems. This is because tradition is an ancestral heritage that must always be preserved so that the younger generation can enjoy it in the future. In addition, tradition as a source of wealth of local wisdom can be implemented wisely in overcoming problems in society to prepare for a better life.

The language and cultural research focus on ritual ceremonies during the early planting period in Wonokromo Village, Alian District, Kebumen. This study attempted to explore the linguistic categories and verbal expressions contained in ritual ceremonies during the early planting period. The ceremony is called nyadran. Nyadran is a tradition that is still maintained by the people of Wonokromo, especially in Tinatah Hamlet. This tradition is a form of concern for the people of Wonokromo in maintaining cultural values so that they are not lost by the flow of globalization. In the Nyadran tradition, there are language and cultural relationships that reflect the mindset of the Wonokromo people.

Some previous studies on antropolinguistics studies and tradisional expresions have been carried out, for examples: [2] focused on local wisdom of communities in Central Java, East Java and the Special Region of Yogyakarta reflected in language categories and expressions. with a variety of forms. In this context the community keeps a knowledge system that is visible in the mindset and outlook of life of farmers. A similar research was also carried out, [3] focuses on verbal and nonverbal categories and expressions in Javanese fishing language and culture, as well as local wisdom contained in the language. and Javanese culture of fishing communities in Kebumen.

Another similar research, [4] this research focuses on the perceptions of the farmer community and their perceptions of non-farmer work including the community's mindset of the existence of ancestral traditions as a form belief and belief in dhyang 'village watchmen', how to maintain ancestral traditions, religious attitudes of the peasant community which are reflected in the verbal and non-verbal expressions of the community. In addition,[5] this research focuses on the cultural meaning in the weak tradition offerings and the procession of the tradition ceremony forty days and a thousand days after death. Furthermore, [6] focuses on the lexical and cultural meanings of the tradition majalan sortana in death ceremonies in the village of Aeng Tong-tong Madura.

The study of language and culture is studied with anthropolinguistics or ethnolinguistics: anthropology as the study of human beings and linguistics studying the intricacies of language. Anthropolinguistics is a study that connects linguistic facts and cultural facts. Linguistics anthropology will be presented as the study of language as a cultural resource and speaking as cultural practice [7]. Linguistic anthropology is an interpretative discipline that examines language to express context-based cultural understanding [8].

According to, Sibarani [9] states that in anthropolinguistic studies there are three studies, namely language studies, cultural studies and studies of other aspects of human life. The three studies are understood based on a linguistic framework (verbal and non-verbal expressions) and anthropology (social and cultural). Ethnolinguistic is the kind of linguistics concerned with the dimension of language (vocabulary, phrases, clauses, discourse, and units lingual others) in the social and cultural dimensions (such as ceremonies, events, cultural folklore, and others) wider to advance and maintaining the practices cultural and social structures of society [10]. 
Researchers are interested in studying this topic with anthropolinguistic studies because anthropolinguistic studies analyse linguistic forms and elements that reveal socio-cultural elements. The purpose of this research is to describe linguistic categories and cultural meanings in the "nyadran" open earth tradition.

\section{Research Methods}

This research is a qualitative descriptive study with an anthropo linguistic approach. This qualitative descriptive method also makes use of ethnographic methods. Ethnographic method is used in this research because data collection uses the work steps of an ethnographer. This research is focused on the linguistic phenomena found in the cultural context of the hill farmer communities in Wonokromo Village, Alian, Kebumen. The analysis model uses the ethnoscience model or also called the new ethnography.

The data in this study include verbal data and non-verbal data. The verbal data is in the form of informants' utterances in the form of lingual units of words, phrases, clauses, and sentences contained in the traditions sranan and nyadran, while non-verbal data is in the form of symbols in the form of different objects or tools and offerings used in the tradition. Sources of data come from selected informants and supporting documents.

Technique purposive sampling is used to determine the informant to be used as a data source, while also using snowball sampling this is because researchers do not yet know all the sources of such data [11]. The data collection techniques used observation and interview techniques [10]. The validity of the data used triangulation of data in the form of data sources and collection methods. Technical data analysis by identifying, classifying, describing, interpreting and making conclusions.

\section{Results and Discussion}

The Wonokromo community has a tradition in the context of agriculture, namely the tradition of opening the earth or nyadran. This ceremony is held annually by the Wonokromo community when the planting period will begin. In the Nyadran tradition, there are forms of both verbal and non-verbal expressions. These languages have cultural significance in individual and group life. The ceremony can be expressed in the form of lingual units in the form of words, phrases, sentences and discourses, while non-verbal expressions are expressed through symbols listed in the offerings used at the Nyadran traditions. Thus, language forms in anthropolinguistic studies are classified into two parts, namely verbal language and non-verbal language in the nyadran tradition.

\subsection{Nyadran Tradition}

Tradition in Latin: traditio, means 'passed on' or 'habit'. Traditions are customs that have been carried out from generation to generation by community groups. Traditions usually come from a country or region, time, religion, or culture. As an agricultural country, Indonesia also has a tradition that is directly related to natural ecology. This tradition has been carried out for a long time, linking humans and the creator of the universe through offerings in the form of traditions. in several agraris areas in Java, this tradition is called nyadran. Nyadranan is a 
traditional ceremony, is one of the cultural heritages and the belief that certain places are considered sacred [12].

Tradition nyadran is one of the traditional ceremonies in agriculture that is still preserved by the Wonokromo community. The traditional ceremony is held when the planting season will start. The nyadran tradition is a celebration ceremony that begins with mutual cooperation activities to clean the graves in the Tinatah, Wonokromo Village. After that, the event continued to slaughter wedhus kendhit pilgrimage event ancestral graves. In the afternoon after Friday prayers, a group of tahlilan is held at the Kadus house.

The purpose of holding this tradition is to welcome the beginning of the planting season so that it is always under the protection of God Almighty and to ask for safety so that during the planting period, blessings and abundant harvests are given. In addition, this tradition is a form of respect for the ancestors and rulers of the rice fields, symbolized by the various offerings used in the ceremony. One of the traditions used in the ceremony is wedhus kendhit which is symbolized as a form of rejecting logs. In addition, the people of Wonokromo want a safe, peaceful and prosperous life.

In this case, nyadran can balance the relationship between (1) hablum minallah (human relationship with God), because with the existence of nyadran humans can get closer to their God through salvation; (2) hablum minan nas (human relations with each other), that humans live in the world cannot be separated from the social aspect. This is because, in essence, humans are individual and social. In other words, it is impossible for humans to escape from socialization in society. Nyadran is one of the media for the Tawun community in creating a harmonious society; and (3) hablum minal 'alam (human relationship with the natural environment).

\subsection{Linguistics Categories and Non-Verbal Expressions in Nyadran Tradition}

Humans live in a symbol system which is actualized in a system of knowledge, art, social and religious values reflected in the form of language[13]. Language systems are realized in the relationship between humans in a conceptual and psychological framework. Language is considered as an expression or expression of the experience of human life, both at the microcosmic and macrocosmic levels of life. Through language that is in the form of speech, ideas can be expressed and understood collectively by humans.

Community life activities related to livelihoods and traditional ceremonies in agriculture have several meanings that cannot be revealed directly but can be revealed through the symbols used in ubo rampe or offerings. Offerings are a form of effort to create harmony through a spiritual path in order to maintain a good relationship between humans and humans, humans and creators, and humans with their surroundings and supernatural beings. The lexicons which are considered to contain symbolic or cultural meanings are lexicons that are expressed verbally, but are spoken non-verbally in the context of Javanese language and culture of the mountain farming community.

\section{Categories of Kewan “animals”}

The categories of animals used in the offerings include goats and chickens. This is due to the geographical condition of the Wonokromo community, which has a lot of goats and chickens. Goats and chickens are used in every traditional ceremony, especially in the nyadran ceremony because they show economic value. Apart from being livestock, goats also have an important spiritual role for offering offerings. In the tradition of nyadran, the goat used is not just any goat, it will still be the type of Wedhus Kendhit. Wedhus Kendhit, namely a goat that has a line that circles the body of the goat. Wedhus Kendhit symbolizes sacrifice and as an intermediary who can reject logs in the form of disasters or calamities. In this context, people 
believe that wedhus kendhit can neutralize negative things. The chicken used in the nyadran tradition is in the form of a rooster made of ingkung or rosulan chicken. This ingkung chicken shows that humans must respect, submit to the creator and the ancestors in the hope of being saved. Goat and chicken are used as offerings to symbolize an expression of offerings to the village dhayang and mbok Sri as the goddess of sustenance.

\section{Categories of Flower "kembang" and menyan "kemenyan"}

Flower 'kembang' is a symbol of fragrance and as a condition to always be given fluency in carrying out the tradition of nyadran. The flowers used in the tradition nyadran are kembang telon 'three kinds of flowers' and kembang wangi 'fragrant flowers'. Kembang telon include kembang kanthil, kembang kenanga, kembang mawar and kembang wangi.

First, the term kembang kanthil is symbolically significant culturally as a form of doctrine to humans. This is so that humans in achieving their desires must go through struggle and sacrifice. This meaning can be interpreted from the term kanthil. Javanese people often use the term otak-atik matuk. The term kanthil can bein the brain to become changed kanthi laku 'with struggle, action'. Kembang kanthil 'bunga kantil' also has a cultural meaning, namely as a human being who has been given knowledge, he must be able to cumanthil or cumanthil 'still attached, remember', this is because this knowledge is used as a guide for life. Second, the kembang mawar symbolically has a cultural meaning as a form of ideals that are expected by the farming community in Wonokromo village.

The community hopes that during the cultivation of the fields until post-harvest they will be avoided from all dangers, both pests that attack rice plants and disasters that be fall the people of Wonokromo. In spirituality, people hope that God the Almighty will be given peace and tranquility of life. This is because the majority of the people in Wonokromo are Muslims who believe that everything that happens is only God's will. Third, the kembang kenanga 'flower of kenanga' according to the perception of the peasant community culturally, people are expected to always be careful in carrying out activities both related to agriculture and in daily life. The term ylang is derived from the recalls 'remember, dekenang' then got affix -a. The affix -a emphasizes the meaning of the command (imperative).

The term kenanga means remember, remember, it means that as a religious community, they always want to remember, remember their ancestors' services who have contributed to opening Wonokromo village. In addition, people must always remember the advice that has been conveyed by their ancestors so that they are always careful in living their social life. Kemabang wangi, Culturally, the people of Wonokromo believe that kembang wangi are one of the foods of spirits in this context, namely mbok Sri. The purpose of the kembang wang $i$ is to reassure spirits so as not to disturb humans and protect farmers' fields. Menyan 'incense' is a powder that is burned and used to impart spirits. According to the beliefs of the people of Wonokromo, it is a means to initiate prayer. In addition, menyan also symbolizes a spiritual attitude and worship to God Almighty which must be maintained.

\section{Categories of Fruits and Vegetables}

Culturally, the Wonokromo community has reflected their mindset, world view, and world view. From this aspect, it is related to the natural conditions around which as an agricultural society. Thus, any ceremonies that offer offerings cannot be separated from the produce in the village. Some of the crops used as ubo rampe or offerings in the nyadran tradition include jengkol, banana, bodin 'cassava', with 'young coconut', and gedhang 'banana'. The offerings are not only complementary, but each offering has a symbolic and cultural meaning in accordance with the context of the farming community in Wonokromo village. 
First, the gedhang 'banana' used in the tradition Sranan includes 1) gedhang raja 'banana' symbolizing the Wonokromo community, they have the view that the village of Wonokromo will be able to produce figures who become a king future 'leader', besides gedhang raja also symbolizes the noble ideals of the people of Wonokromo in advancing the nation and state 2) Gedhang Ambon symbolizes that our life must be filled. This means that we must have external knowledge, both religious knowledge and general knowledge as a guide in living the life to come, 3) gedhang lenga, lexically, bananas are used to feed babies.

Culturally, it is an offering equipment that should not be left behind in the tradition nyadran. Degan, culturally believe that water from this can neutralize diseases that can disturb humans. In addition, water with degan is holy water but does not purify it. According to the Javanese, water with water is considered to have very effective properties to treat all diseases. Then, Jengkol, pete, and bodin culturally show the simplicity of the Wonokromo people in living their lives. In addition, it shows an agrarian society in the context of a hill farming community.

\section{Categories of Food and Beverages}

The type of food used in the offering's tradition Sranan includes kupat lepet, sega golong, grilled chicken, snack market, knapsack and legokan, while the beverage contained in the tradition Sranan namely water jejawutan, coffee legi, coffee pait, tea legi, and pait tea. Culturally, this food has a symbolic meaning as a form of traditional society that still maintains its ancestral heritage. Kupat lepet this symbolizes a good apology to God as the creator of the universe, mbok Sri as the ruler of the fields, ancestors and fellow residents. The people of Wonokromo understand that in living their lives they make many mistakes.

Sega golong, is a symbol of human determination to reach a dream. In this context, the community hopes that the resulting harvest will be satisfactory and in accordance with the expected goals. Ayam panggang is a symbol of resignation to God Almighty, that the results they get are only left to God. jajan pasar are a symbol of simplicity. Legokan is a symbol that we must always be introspective in cultivating rice fields. In addition, the drinks used in the offerings of the tradition Nyadran, in the form of pait coffee, legi coffee, pait tea, legi tea and jejawutan water, are symbols in life that have two complementary sides.

\section{Categories of makeup}

Tradition nyadran there are also offerings in the form of makeup equipment. The offerings include wedak 'powder', kaca 'glass', jungkat "comb' and suri 'suri". Symbolically the offerings are a form of respect and offerings to the dhayang in the fields. Dhayang by community commonly known as Sri mbok or mbok Sruni.This is because the mbok Sri is a symbol of the goddess of prosperity or the goddess of sustenance. All the makeup items have cultural significance as a symbol of beauty. In the context of Islamic teachings, maintaining cleanliness is both an order and a recommendation to always live clean and holy. This is because cleanliness is part of faith.

\section{Conclusion}

Analysis of the relationship between language and culture is able to see different points of view on the meaning of nyadran. The term nyadran is defined by the general public as a form of pilgrimage to the graves of ancestors during the ruwah month. However, it is different from the culture of the Wonokromo people which still maintains the tradition Nyadran. The Nyadran tradition in Wonokromo Village is a tradition of opening the earth or a tradition to start the planting period. Looking at the cultural context, the people of Wonokromo have views and a set 
of knowledge as a form of local wisdom. Based on the linguistic analysis of the data obtained in the form of words, phrases and compound words that express offerings nyadran tradition.

The categorization of the types of offerings in the tradition Nyadran shows that categorization can provide clues to how the offerings function in the tradition Nyadran based on cultural themes in accordance with the cultural context of the community. Categorization is also a reflection of the Javanese perspective on the level of microlinguistics and macro linguistics. Microlinguistics sees culture in terms of the language level which includes lexicons in the form of words, phrases, clauses, sentences and discourses that have cultural meaning based on the cultural context of the Wonokromo community.

Meanwhile, macrolinguistics looks at how this culture affects the mindset, outlook on life, and views of the world. The community has the view that the Nyadran tradition is an ancestral heritage that must be preserved. That way, people's lives will be balanced and harmonious. At the macrolinguistic level, offerings in the tradition are nyadran believed to be able to act as an intermediary to convey messages to the creators and custodians of nature. The message is in the form of hopes and prayers for the community to always be given safety, welfare and protection from various negative influences in the form of disasters or diseases.

\section{References}

[1] Koentjaraningrat, Pengantar Ilmu Antropologi. Jakarta: Rineka Cipta, 2002.

[2] I. Y. Fernandez, "Kategori Dan Ekspresi Linguistik Dalam Bahasa Jawa Sebagai Cermin Kearifan Lokal Penuturnya: Kajian Etnolinguistik Pada Masyarakat Petani Dan Nelayan," Kaji. Linguist. dan Sastra, 2008.

[3] W. Abdullah, "Local Wisdom of the Fishermen's Language and Livelihood Traditions in the Southern Coast of Kebumen, Central Java, Indonesia (An Ethnolinguistic Study)," Int. J. Humanit. Soc. Sci., 2015.

[4] W. Abdullah and D. Purnanto, "KEARIFAN LOKAL PETANI DAN PERSEPSINYA TERHADAP PEKERJAAN NON-PETANI DI KABUPATEN NGAWI (KAJIAN ETNOLINGUISTIK)," Haluan Sastra Budaya, 2017, doi: 10.20961/hsb.v33i2.4256.

[5] H. Hodairiyah, W. A. Rais, and D. Purnanto, "The Cultural Meaning in Verbal and Non Verbal Expression Represented in Nyaébuh Tradition of People in Aeng Tong-tong, Saronggi, Sumenep," Ling. Cult., 2019, doi: 10.21512/lc.v13i4.5933.

[6] H. Hodairiyah, W. A. Rais, and I. Y. Fernandez, "Lexical and Cultural Meanings of Majalan Sortana Tradition in Death Ceremony of Aeng Tong-tong Madura Society," 2019, doi: 10.2991/icalc18.2019.27.

[7] A. Duranti, Linguistic Anthropology. New York: Cambridge University Press, 1997.

[8] Wiliam Foley, Anthropological Linguistics: An Introduction. Sydney: Blackwell, 1997.

[9] R. Sibarani, "Pendekatan Antropolinguistik Terhadap Kajian Tradisi Lisan," RETORIKA J. Ilmu Bhs., 2017, doi: 10.22225/jr.1.1.9.1-17.

[10] W.- Abdullah, Kearifan Lokal dalam Bahasa dan Budaya Jawa: Studi Kasus Masyarakat Nelayan di Pesisir Selatan Kebumen Jawa Tengah (Kajian Etnolinguistik), UNS Press. Surakarta: UNS Press, 2017.

[11] HB Sutopo, Metodologi Penelitian Kualitatif. Surakarta: Sebelas Maret University Press, 2006.

[12] I. Hidayatullah, M. Irwan, and T. Herwanti, "Nyadranan, Bentuk Akulturasi Islam Dengan Budaya Jawa (Fenomena Sosial Keagamaan Nyadranan Di Daerah Baron Kabupaten Nganjuk)," J. LENTERA Kaji. Keagamaan, Keilmuan Dan Teknol., 2017.

[13] A. D. Fuad and Y. T. Hapsari, "LEKSIKON MAKANAN TRADISIONAL DALAM BAHASA JAWA SEBAGAI CERMINAN KEARIFAN LOKAL MASYARAKAT JAWA,” J. Pendidik. Bhs. dan Sastra, 2020, doi: 10.17509/bs_jpbsp.v19i1.20756. 